\title{
Variations in Climate Change Indicators and Implications on Forest Resources Management in Taraba State, Nigeria
}

\author{
Agbidye Francis Sarwuan ${ }^{1,}$, Emmanuel Zando Angyu' ${ }^{1}$, Egbuche Christian. Toochi ${ }^{2}$ \\ ${ }^{1}$ Department of Forest Production and Products, University of Agriculture, Makurdi, Nigeria \\ ${ }^{2}$ Department of Forest and Wildlife Technology, Federal University of Technology Owerri, Imo State, Nigeria
}

Email address:

fagbidye@yahoo.com (A. F. Sarwuan)

\section{To cite this article:}

Agbidye Francis Sarwuan, Emmanuel Zando Angyu, Egbuche Christian. Toochi. Variations in Climate Change Indicators and Implications on Forest Resources Management in Taraba State, Nigeria. Agriculture, Forestry and Fisheries. Vol. 4, No. 6, 2015, pp. $252-256$.

doi: $10.11648 /$ j.aff. 20150406.13

\begin{abstract}
This study was carried out to investigate the variation in climate change indicators of specific interest of rainfall and temperature) in Taraba State from 1991 to 2011. Secondary data were obtained on these climate change indicators from the Nigerian Meteorological Agency (NIMET), Jalingo, Taraba State, Nigeria. Data obtained on amount of rainfall, maximum and minimum temperature and temperature range were subjected to Analysis of Variance (ANOVA). The results showed no significant differences in all the variables considered $(\mathrm{p} \leq 0.05)$. This shows that the much talked about climate change in Taraba State is speculative and not based on empirical data. However, to forestall the possible menace of climate change in the study area, it was recommended that policies and programmes supporting afforestation and proper environmental management should be put in place. Also, there is need for a widespread enlightenment of the citizens on climate change to enable them to change some of the human behaviours contributing to climate change.
\end{abstract}

Keywords: Climate Change, Indicators, Temperature, Rainfall, Implications, Forest Resources

\section{Introduction}

Climate is the composite of the day-to-day weather condition and of atmospheric elements of a place or region, over a long period of time, at least about $30-35$ years [1]. It is further accepted that climate change has been defined as a change in the state of the climate that can be identified (. by using statistical tests) by changes in the mean and/or the variability of its properties, and that persists for an extended period typically decades or longer [2]. Global climate change and warming however, is supported as the rising earth's surface temperature caused by the increase in the concentration and accumulation of green house gases in the atmosphere. Today, climate change is among the major global environmental problems threatening the survival of the entire race. It is seen as a key phenomenon of our times, as a set of events which affects forestry and may alter the lives of human kind in general [2].

Climate change is controlled by factors such as temperature, precipitation (rainfall), solar energy, humidity, wind, air pressure, altitude, latitude, distribution of land and water, mountain barriers and ocean currents [3]. Temperature and rainfall are among the major factors that influence weather conditions of a place and has been documented that major indicators of climate change are the increase in the mean surface temperature [4] and increase in mean annual rainfall [5]. Global records of earth's surface temperature have indicated a rise of about $0.3-7^{\circ} \mathrm{C}$ in temperature in the last century [6]; [7]. Precipitation has increased by about $1 \%$ across the world in the last century, while high latitudes tend to see more rainfall. Temperature changes affect plants in the following ways: Increase in temperature may prevent some plants from growing in their natural areas; abnormal increases in temperature have adverse effects on productivity of forest crops and plants; thereby alters flowering pattern of crops and forest plants species, resultant starvation leads to death and migration of wild species; low temperature could lead to formation of ice which hinders the germination of plants and operation of some important soil microbes that act as decomposers among others. Apart from this, some authors have suggested that climate change could lead to dieback in existing or future forests due to water stress, insect infestations, or fires [8]; [9]; [10].

The association between climate and forestry has widely been discussed in the literature [11]; [12]. There is great 
concern over the implications of a changing climate to the forest industry, particularly since the species and provenances planted at present and in the recent past reflect the current climate. It is now widely recognized that climate change is likely to have strong influences on the structure and function of the forests [13]; [2]. These impacts can be categorized into three general areas that include forest productivity changes, ecosystem disturbances and changes in forest species distributions. Productivity changes are adjustments in the productivity of the forest which alter the growth rates of forest species (in either a positive or negative way), while changes in disturbance influence the standing stock of timber and non-timber species through pest infestation, forest fires, wind-throw, and ice damage. Changes in species distribution results from shift in climate, which ultimately alters the optimal geographic location of different species [14].

There have been widespread speculations about climate change all over the world which in most cases not backed by relevant data that has resulted in such questions as Is climate change real or speculative? This research sought to provide the answer to this question particularly as it relates to Taraba State. This study was therefore carried out to determine whether there is a significant change or variation in the amount and pattern of rainfall and temperature in Taraba State from the inception of the State in 1991 to 2011. The analyses of climate change indicators (particularly rainfall and temperature) in the study area are is of paramount importance to the people of the State. As an agrarian State, climate change will have negative impacts on the overall economy of the State. Therefore, this study was to throw more light on whether there is significant variation in the climate of the State judging from the analyses of rainfall and temperature figures. This will enable the people to take precautions against the possible effects of climate change in the area.

\section{Methodology}

\subsection{The Study Area}

Taraba State is located in the North-East geographical zone of the country, with its head-quarters in Jalingo. It has sixteen (16) Local Government Areas (LGAs). The State has a total land mass of 51,000 kilometer square. It lies roughly between latitude $6^{0} 30^{1}$ and $9^{\circ} 36^{1} \mathrm{~N}$ and longitude $9^{0} 10^{1}$ and $11^{0} 5^{1} \mathrm{E}$. It is bounded on the North-East by Adamawa State and the West and South-East by Plateau and Benue States respectively. On its east border is the Republic of Cameroun. According to the 2006 Census figures released by the National Population Commission (NPC), Taraba State has a population of 2, 294, 800 people [16].

The temperature of Taraba State ranges between $33^{\circ} \mathrm{C}$ and $37^{\circ} \mathrm{C}$; however, in the driest month (March), it could rise to $40^{\circ} \mathrm{C}$. The amount of rainfall in the State ranges between $1350 \mathrm{~mm}$ in the North and $1650 \mathrm{~mm}$ in the South. The rainy season starts in April and ends in October, while the dry season begins in November and terminates in March. The dry season reaches its peak in January and February when the dusty North-East trade wind blows across the State. The climate, soil and hydrology of the State provide a conducive atmosphere for the cultivation of most staple food crops, grazing lands for animals and fresh water for fishing and forestry. As a result of its agrarian nature, the predominant population of the State engages in farming as an occupation. About three quarters (75\%) of the people are farmers while an estimated one quarter (25\%) are engaged in other economic activities [15].

The vegetation of Taraba state comprises of three types of vegetation zones namely: the guinea savannah, which is marked mainly by forest and tall grass is found in the Southern part of the state like Wukari, Takum and Dunga, the sub-sudan type characterized by short grasses is found in Jalingo, Lau, and Ardo-kola, interspersed with short trees, while the semi-temperate zone is found in the central part of the State [15].

\subsection{Data Collection and Analyses}

The data used for this research was secondary data of monthly rainfall and temperature from 1991 to 2011 which were obtained from the Nigerian Meteorological Agency, Jalingo, Taraba State. The data obtained were analyzed using both one way and two way analysis of variance (ANOVA) with mean separation by Fischer's Least Significance Difference (LSD). All probability levels were at 5\% level of significance. The statistical package used was Genstat Discovery Edition 4.

\section{Results}

\subsection{Mean Annual Maximum Temperature $\left({ }^{\circ} \mathrm{C}\right)$}

The results on maximum temperature are presented in Table 1 and Figure 1. There were no significant differences noticed and the temperature trend remained somewhat stable since 1991 to 2011. However, a gradual increase was noticed in the years $1998\left(\operatorname{Tmax}\left({ }^{\circ} \mathrm{C}\right)=34.02 \pm 3.14\right), 2003(\operatorname{Tmax}$ $\left.\left({ }^{\circ} \mathrm{C}\right)=34.60 \pm 3.21\right), 2006\left(\operatorname{Tmax}\left({ }^{\circ} \mathrm{C}\right)=34.23 \pm 3.33\right), 2009$ $\left(\operatorname{Tmax}\left({ }^{\circ} \mathrm{C}\right)=34.04 \pm 3.10\right)$ and $2010 \quad\left(\operatorname{Tmax}\left({ }^{\circ} \mathrm{C}\right)=\right.$ $34.42 \pm 3.44)$. A slight drop was also experienced in the maximum temperature of $1992\left(\operatorname{Tmax}\left({ }^{\circ} \mathrm{C}\right)=32.99 \pm 2.11\right)$ and $1994\left(\operatorname{Tmax}\left({ }^{\circ} \mathrm{C}\right)=32.85 \pm 2.66\right)$.

\subsection{Mean Annual Minimum Temperature $\left({ }^{\circ} \mathrm{C}\right)$}

As indicated in Table 1 , the results on minimum temperature showed no significant differences. There was a slight increase in the minimum temperature in 1998 (Tmin $\left.\left({ }^{\circ} \mathrm{C}\right)=23.08 \pm 2.39\right)$ and $2005\left(\operatorname{Tmin}\left({ }^{\circ} \mathrm{C}\right)=23.38 \pm 2.59\right)$.

\subsection{Temperature Range $\left({ }^{\circ} \mathrm{C}\right)$}

Results on temperature range within the period of study (1991 - 2011) also recorded no significant differences at 5\% level of probability even though the results were fluctuating (Table 1, Figure 1). There was a slight rise in the temperature range in 2003 (Trange $\left.\left({ }^{\circ} \mathrm{C}\right)=12.01 \pm 3.84\right)$. 


\subsection{Rainfall (mm)}

The results on rainfall as indicated on Table 1 and Figure 2 revealed that there were no significant differences in the rainfall distribution for the periods under study (1991-2011). Although a slight increase in rainfall distribution was recorded in $1993(113.30 \pm 109.70 \mathrm{~mm})$ and $2009(129.00 \pm$ $128.60 \mathrm{~mm})$, statistically, the differences were not significant.

Table 1. Mean Annual Temperature and Rainfall Values in Taraba State from 1991-2011.

\begin{tabular}{lllll}
\hline Year & Tmin $\left({ }^{\circ} \mathbf{C}\right)$ & $\left.\operatorname{Tmax}^{\circ} \mathbf{C}\right)$ & Trange $\left({ }^{\circ} \mathbf{C}\right)$ & Rainfall $(\mathbf{m m})$ \\
\hline 1991 & $22.58 \pm 2.34$ & $33.27 \pm 2.70$ & $10.69 \pm 3.59$ & $88.47 \pm 88.46$ \\
1992 & $22.06 \pm 2.33$ & $32.99 \pm 2.11$ & $11.00 \pm 3.37$ & $78.78 \pm 75.56$ \\
1993 & $22.66 \pm 2.08$ & $33.03 \pm 2.02$ & $10.37 \pm 2.49$ & $113.30 \pm 109.70$ \\
1994 & $22.48 \pm 2.41$ & $32.85 \pm 2.66$ & $10.82 \pm 2.94$ & $84.02 \pm 93.91$ \\
1995 & $22.46 \pm 2.59$ & $33.70 \pm 2.70$ & $11.24 \pm 3.40$ & $102.70 \pm 108.50$ \\
\hline
\end{tabular}

\begin{tabular}{lllll}
\hline Year & $\operatorname{Tmin}\left({ }^{\circ} \mathbf{C}\right)$ & $\operatorname{Tmax}\left({ }^{\circ} \mathbf{C}\right)$ & Trange $\left({ }^{\circ} \mathbf{C}\right)$ & Rainfall $(\mathbf{m m})$ \\
\hline 1996 & $22.04 \pm 3.18$ & $33.38 \pm 3.12$ & $11.34 \pm 4.52$ & $112.20 \pm 115.50$ \\
1997 & $22.34 \pm 2.04$ & $33.15 \pm 2.01$ & $10.81 \pm 2.88$ & $72.58 \pm 78.15$ \\
1998 & $23.08 \pm 2.39$ & $34.02 \pm 3.14$ & $10.20 \pm 4.36$ & $75.10 \pm 83.66$ \\
1999 & $22.83 \pm 2.40$ & $33.73 \pm 2.56$ & $10.91 \pm 3.04$ & $90.92 \pm 94.83$ \\
2000 & $22.47 \pm 2.04$ & $33.53 \pm 2.65$ & $11.07 \pm 3.12$ & $76.93 \pm 83.23$ \\
2001 & $22.27 \pm 2.81$ & $33.89 \pm 2.94$ & $11.62 \pm 3.88$ & $85.15 \pm 110.40$ \\
2002 & $22.66 \pm 2.68$ & $33.52 \pm 2.83$ & $10.86 \pm 3.65$ & $103.70 \pm 109.10$ \\
2003 & $22.51 \pm 2.32$ & $34.60 \pm 3.21$ & $12.01 \pm 3.84$ & $59.88 \pm 66.83$ \\
2004 & $22.30 \pm 2.13$ & $33.97 \pm 2.95$ & $11.68 \pm 3.98$ & $69.50 \pm 84.54$ \\
2005 & $23.38 \pm 2.59$ & $33.87 \pm 3.16$ & $10.49 \pm 3.42$ & $71.03 \pm 78.54$ \\
2006 & $22.89 \pm 2.90$ & $34.23 \pm 3.33$ & $11.34 \pm 3.86$ & $76.97 \pm 91.23$ \\
2007 & $22.54 \pm 2.33$ & $33.82 \pm 3.04$ & $11.28 \pm 3.82$ & $79.32 \pm 71.87$ \\
2008 & $22.74 \pm 1.92$ & $33.73 \pm 2.66$ & $10.99 \pm 3.02$ & $102.80 \pm 109.00$ \\
2009 & $22.49 \pm 2.36$ & $34.04 \pm 3.10$ & $11.55 \pm 3.85$ & $129.00 \pm 128.60$ \\
2010 & $22.34 \pm 2.87$ & $34.42 \pm 3.44$ & $10.71 \pm 4.27$ & $82.60 \pm 111.60$ \\
2011 & $22.63 \pm 2.33$ & $33.85 \pm 3.08$ & $11.37 \pm 3.28$ & $76.85 \pm 87.44$ \\
\hline
\end{tabular}

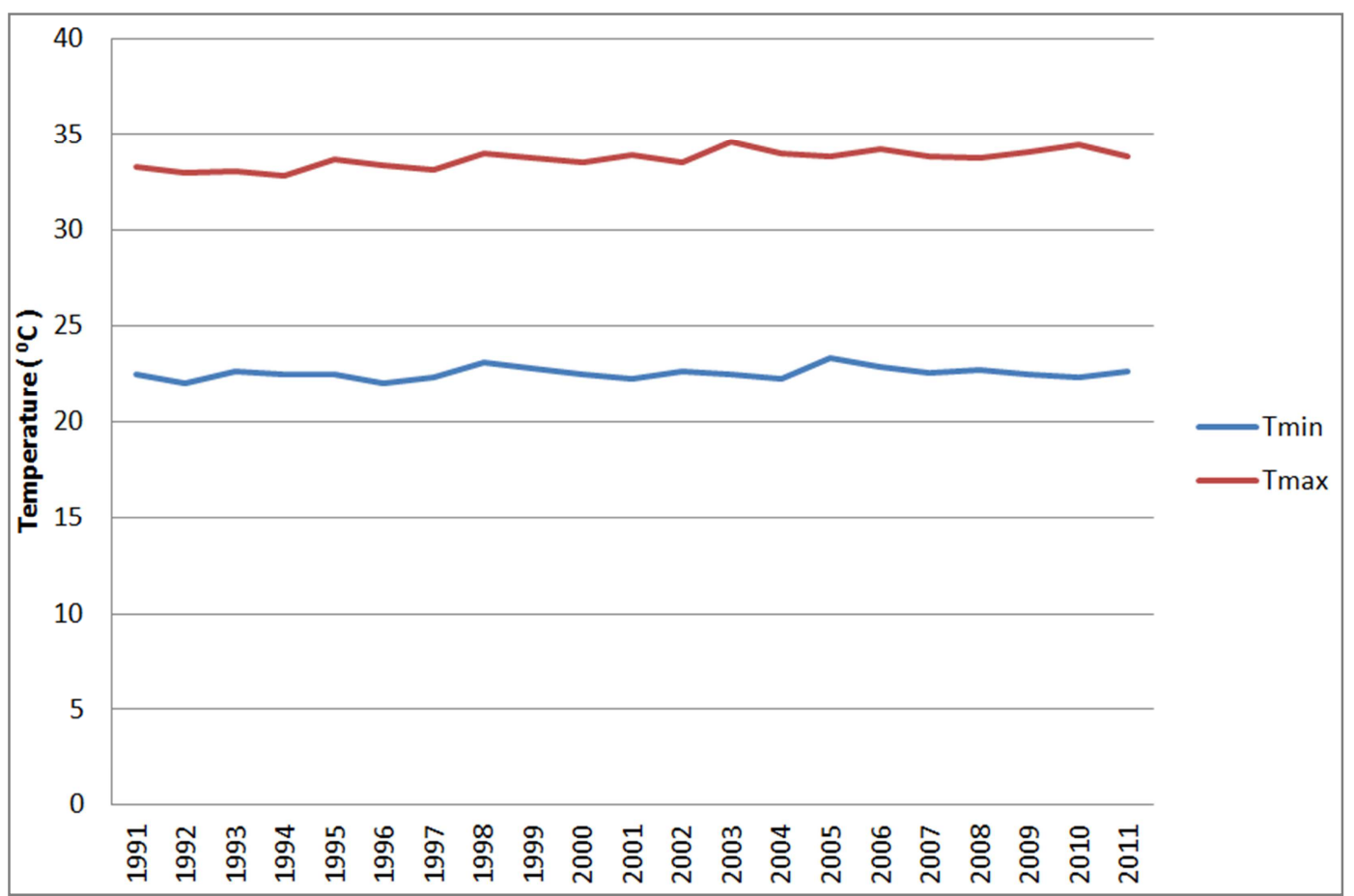

Figure 1. Mean Annual Temperature $\left({ }^{\circ} \mathrm{C}\right)$.

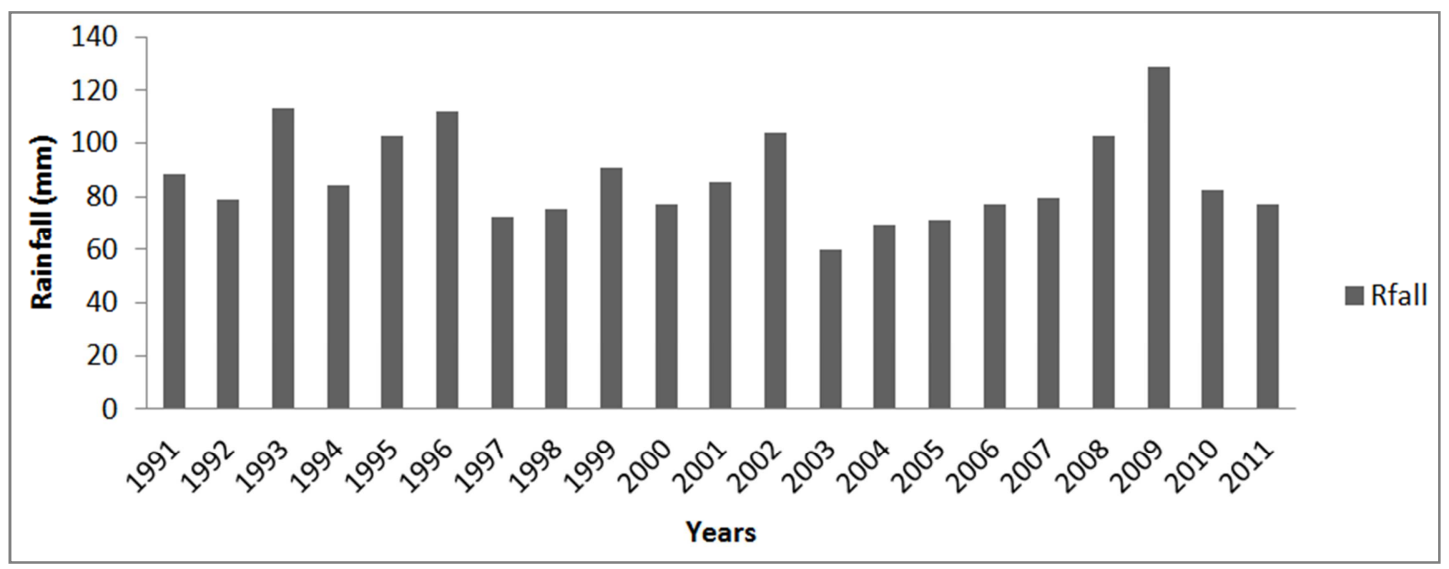

Figure 2. Mean Annual Rainfall (mm). 


\section{Discussion}

This study has revealed a steady rise in temperature in Taraba State during the period under review even though significant differences were not observed. This is observed is in agreement with the global trend [2]. Similarly, [17] also recorded a slight difference in temperature within the late 1940s and early 1960s in Nigeria. The rise in the minimum temperature also agreed with [18] that the earth has warmed by $0.6 \pm 0.2^{\circ} \mathrm{C}$ on the average since 1900 . The findings also conform to those of [19] who reported that the climatic records and the statistical manipulation of daily records of temperature, rainfall and other parameters have shown considerable variations over the years.

The rise in temperature range recorded in the study was in conformity with [20], that in Africa, it has been predicted that by 2100 , temperatures could rise between $2^{\circ} \mathrm{C}$ to $6^{\circ} \mathrm{C}$ relative to what is obtained at present. Despite the fact that that there were no significant differences in the trends, the area under study (Taraba State) still experienced some level of warmth within the years of study (1991-2011). It is worth mentioning that if the temperature trends continue to increase, there is the possibility of Taraba State experiencing a warmer climate in the near future?

The increase in the amount of rainfall recorded in Taraba State within the period under study agrees with [20] who predicted that there would be corresponding increases in mean global precipitation (from $2.5-5.1 \%$ ) with regional differences that include significant localized reductions in annual precipitation. Also, the distribution of rainfall across the months showed higher concentrations mostly around July, August and September in most of the years. Some of the years may not have much rainfall, but because of such concentration of rainfall intensity, the soil may not be able to accommodate moisture any longer, and this could lead to high runoff that makes the volume of water in the rivers rise and consequently overflow as flood, causing all sorts of destruction; as has been experienced severally in the study area (Taraba State). This indicates that the effects of climate change could be enormous all over the world. For example, [21] wrote that United States will suffer a wide range of increasingly extreme weather events in the coming decades as a result of global warming from drought and excessive heat to wildly destructive hurricanes and record floods triggered by intense rains. Furthermore, [22] noted that impacts of climate change include increasing water scarcity and flood risk, along with decline in water quality.

\section{Conclusion}

Slight variations were noticed in the temperature trends (maximum, minimum and temperature range) and also in the rainfall distribution within the period under investigation (1991 and 2011). The variations in temperatures (maximum, minimum and range) and the rainfall distribution in the study area (Taraba State) showed that climate change is unequivocal and climate change indicators are becoming stronger; and therefore, the effects of climate change on forest resources and the environment as a whole are generally becoming threatening in the study area (Taraba State).

\section{Recommendations}

To forestall the possible menace of climate change in the study area, the following are hereby recommended:

- Policies and subsidy programmes supporting private forestry management and reforestation should be put in place.

- Ministry of environment should enforce various laws on conservation and proper management of the environment.

- There should be the integration of climate change impacts information into the general planning process; and

- There is need for a widespread enlightenment of the citizens on climate change to enable them to change some of the human behaviours contributing to climate change.

\section{References}

[1] I. J. Ekpoh. Environmental Change and Management. St. Paul's Printing Company, Calabar, Nigeria. 2002. pp. 63-94.

[2] Intergovernmental Panel on Climate Change (IPCC). Impacts, Adaptation and Vulnerability. Working Group II Report. 2007. (available at www.ipcc.ch).

[3] World Resources Institute (WRI). World Development Reports. Development and the Environment. The World Bank, OUP, Oxford, U.K. 1992. pp. 160-177.

[4] S. I. Udofia. Economic Approaches in Valuing the Effects of Climate Change on Environment .The Nigerian Journal of Forestry. 2001. 31(1\&2): pp105-110.

[5] W. P. Cunningham and M. A. Cunningham. Principles of Environmental Science Inquiry and Applications, 2nd edition. McGraw-Hill Companies Inc. New York, U.S.A. 2004. pp. 201-210.

[6] M. L. Wilki. Climate Change, Forests and SIDs. The International Forestry Review. 2002. 4(4): 313-316.

[7] D. K. Asthana and M. Asthana. Environment: Problems and Solutions. S. Chand and Company LTD; Ram Nagar, New Delhi, India. 2006. pp. 208-218.

[8] A.M. Solomon and A.P. Kirilenko. Climate Change and Terrestrial Biomass: what if trees do not migrate? Global Ecology and Biogeography Letters. 1997. Vol.16, 139-148.

[9] D. Bachelet, R.P. Nelson, J.M. lenihan, R.J. Drapek. Regional Differences in the Carbon source-Sink: Potential of Natural Vegetation in the U.S.A. Environmental Management, 2004. 33: $23-43$. 
[10] M. W. Scholze, N. W. Knorr, Arnell, and I.C. Prentice. A Climate risk Analysis for world Ecosystems. Proceedings of the National Academy of SEED-UNDP (2000): Sustainable Energy Strategies: Materials for Decision - Makers. 2006. 208pp.

[11] L. C. Nwoboshi.. Tropical Silviculture, Principles and Techniques. Ibadan University Press, Nigeria. 1982. pp. 333.

[12] T. O. Amusa. The Role of the Forests in the Amelioration of the Nigerian Environment. The Nigerian Field. Bachelet, d., R.P. Nelson, T. Hickler, R.J. 2002. Vol.67 part 1. Pp 31-43.

[13] R. T. Watson, I. R. Noble, B. Bolin, N.H Ravindranath, D.J. Verardo, and D.J. Dokken (eds). Land use, Land-use Change, and Forestry, 2000. Special Report of the Inter-Governmental Panel on Climate Change. Cambrige University Press, Cambrige.

[14] A. L. Westerling, H.G. Hidalgo, D.R. Cayan, and T.W. Swetnam. Warming and Earlier Spring Increase, Western U.S. Forest Wild life Activity. Science. 2006. 313: 940-943.

[15] Ministry of Information and Social Development, Jalingo, Taraba State. 2007.

[16] National Population Commission, NPC. Federal Republic of Nigeria Official Gazette 2007. No. 24 Volume 94 Lagos, Nigeria.
[17] J. O. Ayoade. Climate Change, Vantage Publishers, Ibadan. 2003. pp. 45-46.

[18] Commonwealth Scientific and Industrial Research Organization (CSIRO). Climate Change Projections for Australia. Summary Document CSIRO, Cauberra. Ekanade, O., Ayanlade, A. and Orimoogunje, I.O.O. (n. d). Geospatial Analysis of Potential Climate Impacts on Coastal Urban Settlements of Nigeria for the 21st Century. GSDI 10 Conference Proceedings. 2001. pp. 12.

[19] E. O. Aina and S.A. Adejuwon. Regional Climate Change: Implication on Energy Production in the Tropical Environment in: Jerome, C. and Umolu, P.E. (eds) The Proceeding of the International Workshop on Global Climate Change: impact on Energy Development, March 28-30, 1994, Lagos, published by Dunatech Nigeria limited.

[20] M. Hulme. Climate perspective in Sahelian Desiccation: 19731998. Global Environmental Change. 2001. 11: 19-29.

[21] C. Miller. Climate Change. A Publication of Newser U.S. 2008. pp. 2.

[22] J. Anderson, K. Arblaster and J. Bartely. Climate Change Induced Water Stress and its Impacts on Natural and Managed Ecosystems. A publication of Institute for International and European Environmental Policy. 2008. pp.1-3. 